\title{
Diet of Limacina helicina (Gastropoda: Thecosomata) in Arctic waters in midsummer
}

\author{
R. W. Gilmer, G. R. Harbison \\ Woods Hole Oceanographic Institution, Woods Hole, Massachusetts 02543, USA
}

\begin{abstract}
The diet of Limacina helicina (Phipps) was examined from in situ collections of adult individuals made during 2 cruises in Arctic waters. Zooplankton, consisting mainly of small copepods and juvenile L. helicina, made up almost half of the mass of material found in digestive tracts of the 28 individuals examined. In contrast, these prey made up a much smaller fraction of the total mass of material in water samples and were only occasionally found as fragments in fecal pellets. A high percentage of diatoms appeared to pass intact through the guts of these pteropods. It appears that motile prey, including tintinnids, copepods, and juvenile L. helicina, are major constituents of the diet of adult L. helicina in midsummer in Arctic waters. This provides additional evidence that thecosome pteropods trap large, fast-moving prey in addition to feeding on fine suspended material.
\end{abstract}

\section{INTRODUCTION}

The euthecosome pteropod Limacina helicina (Phipps 1774), first described from Arctic waters by Martens (1675), is now known to be a common inhabitant of both the Arctic and the Antarctic (van der Spoel 1967, Bé \& Gilmer 1977). Despite its abundance there and its excursions into lower latitudes, such as off the coast of California in the California Current (McGowan 1963), little is known of its biology and natural history.

Limacina helicina has a sinistrally coiled shell, which reaches a diameter of $14 \mathrm{~mm}$. As with members of the Cavoliniidae, limacinids use a large, spherical external mucous web (Gilmer \& Harbison 1986) to collect a wide range of different food types (Lalli \& Gilmer 1989). These delicate webs are difficult to see. During the daytime, they can only be observed in strobe-lit photographs, or made visible by the gentle application of dye. These mucous webs have never been collected, so there is not even a qualitative description of their contents. The webs are difficult to collect, because euthecosomes are easily disturbed, and quickly withdraw or destroy them (Gilmer \& Harbison 1986).

Dietary studies of thecosome pteropods are difficult since they do not feed normally in the laboratory. Previous analyses have largely been limited to gut content studies of preserved, net-collected specimens (e.g. Boas 1886, Meisenheimer 1905, Tesch 1913, Morton 1954, Mironov 1977, Richter 1977. Hopkins 1987. Ishumaru et al. 1988) or to studies of the composition of fecal pellets (Silver \& Bruland 1981), Large metazoan prey such as veligers and juvenile gastropods, small crustaceans, and even eye parts from heteropods and alciopid worms have been found in their guts (see review in Lalli \& Gilmer 1989). These larger prey are usually sparse and are mixed with many intact phytoplankton cells and protozoans. Meisenheimer (1905) believed that the appearance of large food items in the guts was at best due to chance. The only readily identifiable material in fecal pellets consists primarily of hard-bodied phytoplankton and small thecate protozoa (mostly dinoflagellates and Sarcodina). Based on these studies of gut and fecal material and an erroneous description of their feeding mechanism (e.g. Yonge 1926, Morton 1954, Gilmer 1974), thecosomes have been generally regarded as strict herbivores, feeding on fine suspended particles.

Richter (1977) pointed out that, on a volume basis, large zooplankton form a significant part of the diet of many euthecosomes. This led him to suggest that thecosomes should more appropriately be regarded as mucous trappers ('Fallensteller') rather than collectors or suspension feeders ('Sammler'). The discovery that all euthecosomes feed with a large external mucous web revealed an obvious mechanism for entrapping large, fast-moving prey (Gilmer \& Harbison 1986). In contrast to other suspension feeders, euthecosomes lack a mechanism for moving water through their mucous webs (Gilmer 1990).

On night dives, the absence of diffused surface 
illumination makes the feeding webs easier to observe, but lights held by divers appear to affect the behavior of the pteropods. Some species, particularly the vertically migrating Cuvierina columnella, quickly ingest the webs and sink. On several such occasions, we have seen numerous small crustaceans (ca $1 \mathrm{~mm}$ ) trapped inside the webs as they were ingested. Larger hyperiid amphipods ( 3 to $4 \mathrm{~mm}$ in length), attracted by our dive lights, could also become entangled, but were usually able to break free before they were eaten. The smaller crustaceans were unable to escape, however, and were ingested. Those cavoliniids that we have handcollected at night all contained copepods in their guts (Gilmer 1990)

At the time of this study, the sun did not set, so night dives were not possible. Nevertheless, large zooplankton comprised a large fraction of the diet of Limacina helicina. In this paper, we will show that, at least during the summer months, larger zooplankton represented an important fraction of the diet of this species. This study adds credence to Richter's speculation, and provides the first information on the diet of this important pteropod in Arctic waters during summer.

\section{MATERIALS AND METHODS}

Limacina helicina was investigated on 2 cruises aboard RV 'Endeavor': Cruise 133 in August 1985 from Iceland to Newfoundland via the Greenland and Labrador currents, and Cruise 182 in August 1988 from Iceland to Norway via Spitsbergen. On Cruise 182 temperature salinity profiles were made of the upper $65 \mathrm{~m}$ at most stations using a portable CTD (SeaCat

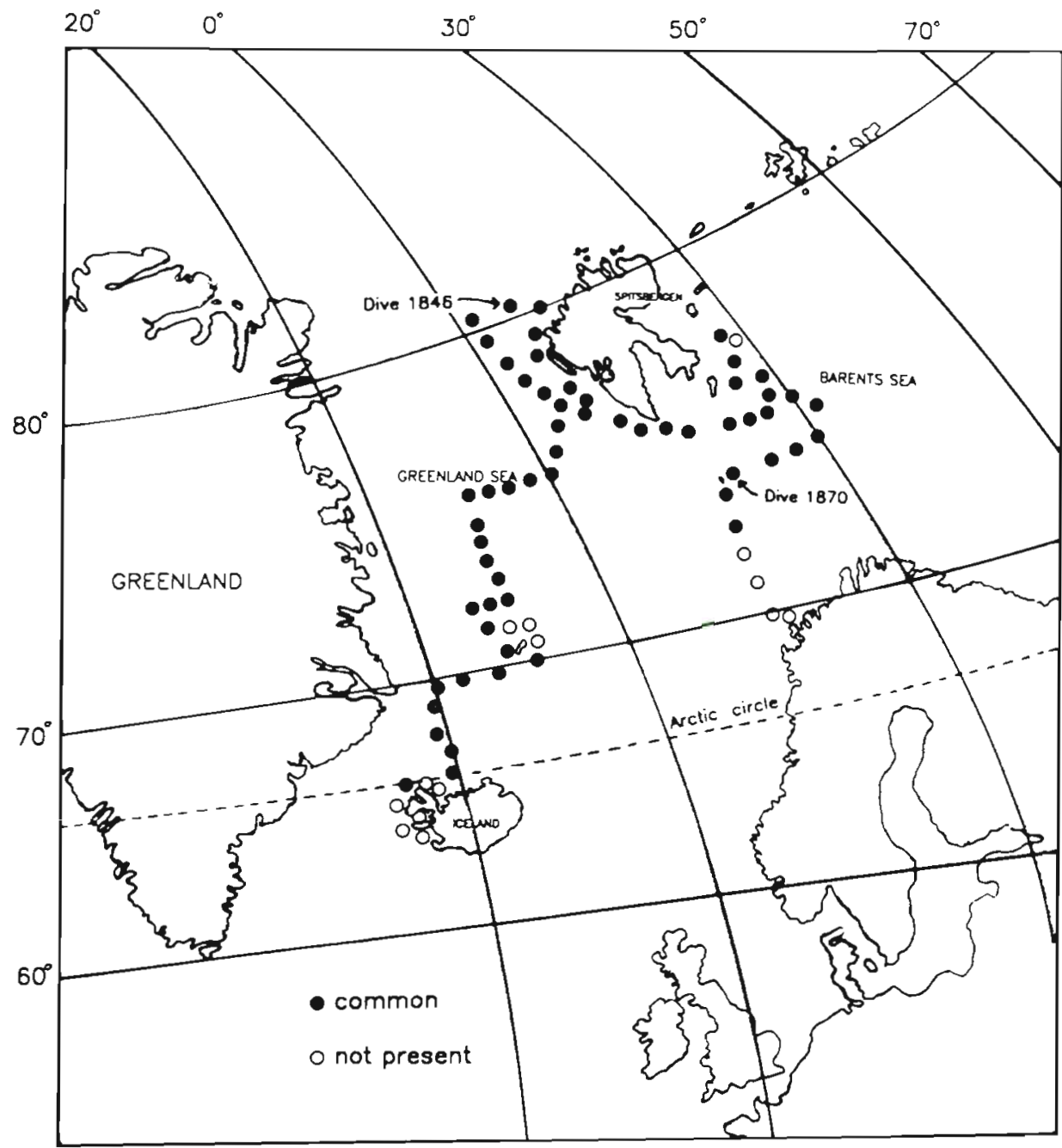

Fig. 1. Limacina helicina. Distribution of pteropods during RV 'Endeavor' Cruise 182 
Profiler: SeaBird Electronics) lowered over the side of the ship. Chlorophyll measurements were provided by M. Putt (methodology given in Putt 1990) from water casts taken at dive stations. Locations of the dive stations for Cruise 182 are shown in Fig. 1. In situ collections using hand-held glass jars were made with standard blue-water diving techniques (Hamner 1975). We observed and collected specimens of $L$. helicina with shell diameters between 5 and $13 \mathrm{~mm}$, which divers could easily see. The abundance of $L$. helicina in this size category was estimated by measuring the nearest neighbor distance between individuals (Hamner \& Carlton 1979). Visual reference markers $(5 \mathrm{~cm}$ intervals) placed on the diver tether line or on a separate piece of quarter-inch nylon rope were used to estimate distances. Since $L$. helicina is easily disturbed, measurements were made quickly. Nearest neighbor distances were rounded to the nearest $5 \mathrm{~cm}$, producing a standard error of \pm 0.25 ind $\mathrm{m}^{-3}$. The distances between 20 to 50 pteropods at each depth were measured. To assess the activities of $L$. helicina, a diver swam through the zone of highest density and observed individuals at random until 6 to 10 active individuals were counted. Most individuals were not swimming but were motionless in the water.

From previous observations on other species (Gilmer \& Harbison 1986, Gilmer 1990), we assume that motionless Limacina helicina were feeding. Inactive individuals were collected in small jars $(100$ to $250 \mathrm{ml}$ capacity) in 3 ways: (1) some were fixed in situ immediately upon capture by injecting several $\mathrm{ml}$ of $10 \%$ formaldehyde (buffered with sodium borate and diluted with seawater) through a rubber serum stopper fitted to the jar lid; (2) others were returned to the laboratory and kept for up to $12 \mathrm{~h}$ to produce fecal pellets; or (3) some were collected in situ but preserved at various intervals over $12 \mathrm{~h}$ to determine the effect of time on gut contents. Pteropods preserved in the laboratory were first relaxed in dilute MS-222 (Ethyl m-aminobenzoate, Sigma) and carefully observed to be sure that material in the guts was not voided during preservation.

Water samples of 1 l were collected with plastic bottles by divers in the layer of maximal pteropod abundance to estimate the number of potential food items in the water. These water samples were preserved on board with filtered $(0.45 \mu \mathrm{m}) 10 \%$ formaldehyde buffered with sodium borate to make a $3 \%$ final solution. The samples were allowed to settle for $1 \mathrm{wk}$ and concentrated into $50 \mathrm{ml}$ jars. The entire sample was examined later for zooplankton under a dissecting microscope. Protozoa and phytoplankton were counted by resuspending the sample and counting ten $1 \mathrm{ml}$ subsamples with a Segwick-Rafter chamber and Olympus compound microscope (fitted with both bright-field and chlorophyll epifluorescence illuminators with blue 490 IF exciter filter).

We removed the gizzard sac and esophagus under a dissecting microscope and examined the entire contents at 100 or $200 \times$ with a compound microscope. All food items larger than $10 \mu \mathrm{m}$ were counted and classified. Cell volume was determined by calculating approximate cell shape from standard geometric forms and applying average values to all particles in each size category (see Table 1). For tintinnids, estimates of volumes were often made from measurements of empty loricae. Carbon values were based on values reported in the literature or calculated from published equations that best represented the size categories of food items (Table 1). Values used for volume ind. ${ }^{-1}$ were obtained from the mean dimensions for each taxon and size category in Table 1. Particles smaller than $20 \mu \mathrm{m}$ were counted but not classified. A spherical volume assuming a diameter of $15 \mu \mathrm{m}$ for each particle of this fraction was used to estimate their volume (Table 1) and carbon. Counts of particles under $10 \mu \mathrm{m}$ were not attempted after initial examinations. These particles were present in all samples, but their contribution to the total volume was always minimal. Total volume was calculated by summing the volumes of all particles greater than $10 \mu \mathrm{m}$.

Animals held to produce fecal pellets were kept in their collection jars at field temperature on board ship and were examined hourly. Pellets were removed as soon as they were produced and either examined immediately or frozen and examined from 1 to 8 mo later. The entire pellet was examined (200 or $400 \times$ ) and all items larger than $10 \mu \mathrm{m}$ were counted and classified. The presence of red fluorescence was used as a criterion to determine if a cell was intact in cases where the cell walls appeared to be disrupted. To check the way in which preservation and storage time affected epifluorescence, both frozen and preserved fecal pellets from Limacina helicina collected in 1985 (Cruise 133) were examined prior to Cruise 182 (35 mo later). Both types of material had comparable numbers of fluorescent cells. Because a high percentage of the pellet consisted of cells between 10 and $20 \mu \mathrm{m}$, an ocular grid divided into 100 squares was used as a reference to count them. Five to ten grid counts were made randomly for each pellet. The counts were then averaged and extrapolated to obtain values for the total pellet area. Total volumes of both the gut contents and fecal pellets were calculated by summation of these counts.

At our 2 study stations (see Fig. 2), hand-held net tows were made by a diver at 3 depths to compare the abundance of potential prey with amounts of prey in the guts of the pteropods. Samples were taken above (4 to $9 \mathrm{~m})$, in $(12$ to $20 \mathrm{~m})$, and below $(25$ to $30 \mathrm{~m})$ the depth of maximum Limacina helicina densities. Each $100 \mu \mathrm{m}$ mesh net had a $15 \mathrm{~cm}$ opening. A separate net 
was used at each depth and the cod ends were tied off under water after the tow, in order to insure that none of the sample was lost. Each net was pushed through the water by the diver for a distance of $20 \mathrm{~m}$. The volume sampled at each depth was ca $0.35 \mathrm{~m}^{3}$. Samples were preserved in $4 \%$ buffered formaldehyde and counted in their entirety.

\section{RESULTS}

On both cruises, Limacina helicina usually occurred in dense layers at depths between 5 and $25 \mathrm{~m}$ (Fig. 2a, b). Temperature/salinity profiles were extremely variable (Fig. 3a, b), but the occurrence of L. helicina was generally in the mixed zone between the surface and the deeper, more stable water. The pteropods tended to avoid the upper $4 \mathrm{~m}$ (possibly because of turbulence) and were usually present in highest concentrations above the thermacline. On Cruise $182, L$. helicina occurred at $87 \%$ of the stations where the surface temperature was below $8{ }^{\circ} \mathrm{C}$. It was particularly abundant in the Greenland and Barents Seas and at most stations around Spitsbergen (Fig. 1). Nearest neighbor measurements indicated that the near-surface abundance maximum was usually between 10 and $24 \mathrm{~m}$. Densities ranged between 1.5 and 2.5 ind. $\mathrm{m}^{-3}$ (Fig. $1 \mathrm{a}, \mathrm{b}$ ). More than $97 \%$ of the ca 1200 individuals we counted were neutrally buoyant and motionless. Net tows indicated that copepods were also abundant in these layers (Fig. 2a, b) Chlorophyll levels were uniformly low in the surface waters at most stations (Fig. 2).

\section{Gut contents}

Small crustaceans (mostly copepod nauplii; Table 1) and Limacina helicina juveniles (Table 1) accounted for an average of $46 \%$ of the total volume (Fig. $4 \mathrm{a}$ ) and an average of $40 \%$ of the estimated carbon (Fig. 4 b) in the guts of specimens preserved in situ $(n=30)$, yet contributed a negligible amount to the total particle count (Table 2). Large thecate dinoflagellates (Group II; Table 1) accounted for an average of $7 \%$ of the volume and $4 \%$ of the available carbon. Tintinnids comprised $15 \%$ of the volume and $19 \%$ of the estimated carbon. At least 5 species of tintinnids were found in the gut contents but were not identified (Fig. 5a shows some of these species).
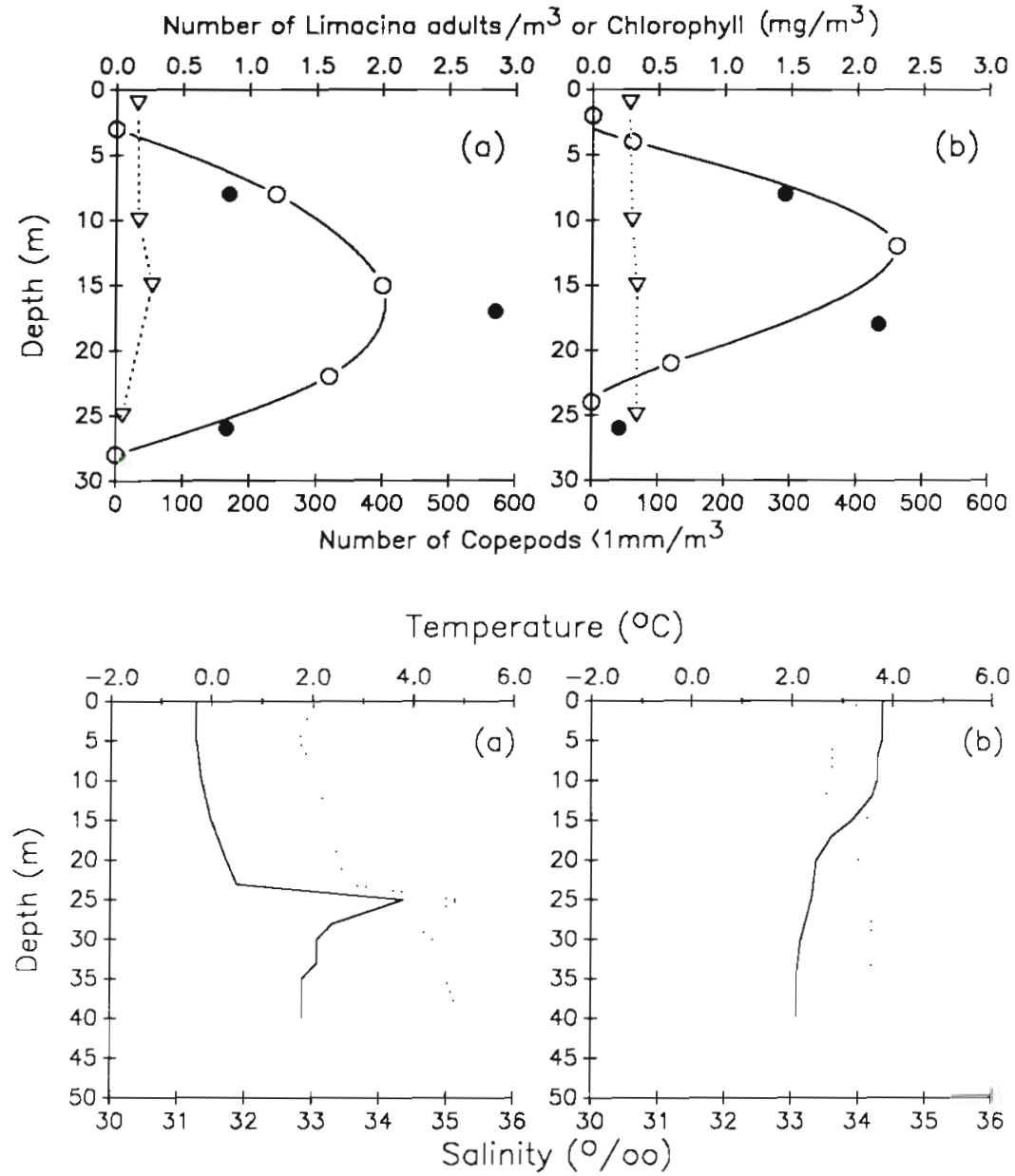

Fig. 2. Comparison of abundance of large $(5$ to $13 \mathrm{~mm}$ ) Limacina helicina (0), of small ( $\leq$ $1 \mathrm{~mm})$ crustacean zooplankton $(\bullet)$, and chlorophyll concentration ( $\nabla$ ). (a) Dive 1846: 7 August $1988,80^{\circ} 39.88^{\prime} \mathrm{N}, 14^{\circ} 27.15^{\prime} \mathrm{E}_{\mathrm{i}}$ (b) Dive 1870: 16 August $1988,74^{\circ} 43.88^{\prime} \mathrm{N}$, $20^{\circ} 37.53^{\prime} \mathrm{E}$. Abundance of L. helicina calculated from nearest neighbor distances; abundance of zooplankton obtained from plankton tows; chlorophyll concentration determined fluorometrically

Fig. 3. Temperature (-) and salinity $(\cdots)$ profiles at Dive Stations 1846 (a) and 1870 (b). Compare with Fig. 2 
Table 1. Limacina helicina. Volume and carbon values assigned to food items shown in Table 2 and Figs. $4 \& 6$. For each food item, average dimensions $\pm \mathrm{SD}$ are given, as well as the size range (in parentheses)

\begin{tabular}{|c|c|c|c|c|}
\hline Food item & Avg. dimensions & $\begin{array}{c}\text { Avg. vol ind } .^{-1} \\
\left(\mu \mathrm{m}^{3}\right)\end{array}$ & $\begin{array}{c}\text { Avg. } \text { (ng) }^{-1} \\
\text { ind }\end{array}$ & Source \\
\hline Copepod nauplii (thorax length) & $180 \pm 65(100-650)$ & $3 \times 10^{6}$ & 90 & Mullin \& Brooks (1970) \\
\hline L. helicina juveniles (shell diameter) & $160 \pm 35(130-270)$ & $2 \times 10^{6}$ & $75^{\circ}$ & Conover \& Lalli (1974) \\
\hline Tintinnids (lorica) & $\begin{array}{l}100 \pm 35 \times 45 \pm 16 \\
(40-300) \times(30-85)\end{array}$ & $2 \times 10^{5}$ & 10 & Verity \& Langdon (1984) \\
\hline $\begin{array}{l}\text { Dinoflagellates } \\
\text { Group I } \\
\text { Group II }\end{array}$ & $\begin{array}{l}34 \pm 8(25-58) \\
90 \pm 5(75-102)\end{array}$ & $\begin{array}{l}2 \times 10^{4} \\
4 \times 10^{5}\end{array}$ & $\left.\begin{array}{l}1 \\
9\end{array}\right)$ & \\
\hline $\begin{array}{l}\text { Diatoms } \\
\text { Centric } \\
\text { Pinnate Group I } \\
\text { Pinnate Group II }\end{array}$ & $\begin{array}{c}47 \pm 13 \times 25 \pm 3(28-60) \\
86 \pm 12 \times 30 \pm 3(66-98) \\
154 \pm 5 \times 35 \pm 4 \\
(104-188) \times(28-40)\end{array}$ & $\begin{array}{l}4 \times 10^{4} \\
8 \times 10^{4} \\
2 \times 10^{5}\end{array}$ & $\begin{array}{l}1.6 \\
2.7 \\
5.5\end{array}$ & Mullin et al. (1966) \\
\hline $\begin{array}{l}\text { Cells } 10-20 \mu \mathrm{m} \\
{ }^{A} \text { Excludes } C \text { of shell }\end{array}$ & & $2 \times 10^{3}$ & 0.2 & \\
\hline
\end{tabular}

Fig. 4. Limacina helicina. Relative frequency $(\%)$ of intact food items in water samples, gut contents, and fecal pellets, for pteropods collected in situ at the 2 dive sites (a) by volume and (b) by carbon, using values from Table 1 . Although fragments of pteropod shells, copepod exoskeletons and empty tintinnid loricae were found in guts and pellets, this material was not scored for this figure a Dive 1846

Dive 1870
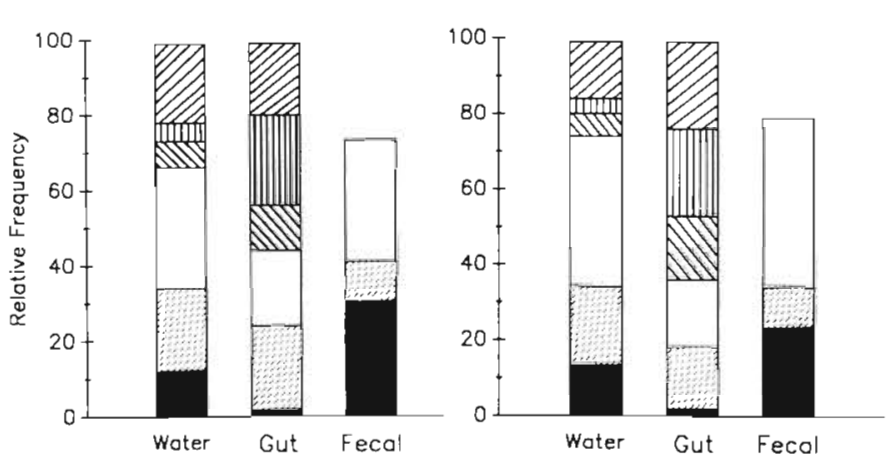

b

Dive 1846

Dive 1870

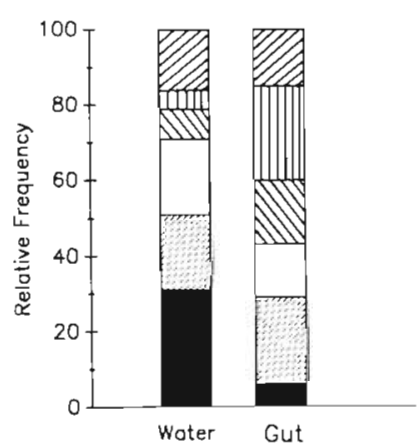

EZ] copepods

III Limacina juv.

$\Delta$ tintinnids

$\square$ diatoms

ए] dinoflogellates

Cells 10 to $20 \mu \mathrm{m}$ 
Table 2. Limacina helicina. Comparison by taxa of total number of intact food items in water samples, guts and fecal pellets for pteropods sampled at 2 dive sites (see legend to Fig. 2). n: total numbers of guts or pellets examined numbers in parentheses in gut content columns refer to the number of specimens with intact food ltems in their guts. Although fragments of pteropod shells, copepod exoskeletons and empty tintinnid loricae were found in guts and pellets, this material was not scored in this table

\begin{tabular}{|c|c|c|c|c|c|c|}
\hline \multirow[t]{2}{*}{ Taxon } & \multicolumn{3}{|c|}{ Dive 1846} & \multicolumn{3}{|c|}{ Dive 1870} \\
\hline & $\begin{array}{c}\text { Water } \\
\left(\text { no. } 1^{-1}\right)\end{array}$ & $\begin{array}{c}\text { Guts } \\
(\mathrm{n}=18)\end{array}$ & $\begin{array}{l}\text { Pellets } \\
(\mathrm{n}=11)\end{array}$ & $\begin{array}{c}\text { Water } \\
\left(\text { no. } l^{-1}\right)\end{array}$ & $\begin{array}{c}\text { Guts } \\
(\mathrm{n}=10)\end{array}$ & $\begin{array}{c}\text { Pellets } \\
(\mathrm{n}=9)\end{array}$ \\
\hline Cells $10-20 \mu \mathrm{m}$ & 6870 & $4592(18)$ & 9740 & 7390 & $2894(10)$ & 8310 \\
\hline $\begin{array}{l}\text { Thecate dinoflagellates } \\
\text { Group I }(\bar{x}=34 \mu \mathrm{m}) \\
\text { Group II }(\bar{x}=90 \mu \mathrm{m})\end{array}$ & $\begin{array}{r}552 \\
35\end{array}$ & $\begin{array}{rr}2851 & (18) \\
97 & (15)\end{array}$ & $\begin{array}{r}327 \\
0\end{array}$ & $\begin{array}{r}480 \\
28\end{array}$ & $\begin{array}{rr}1574 & (10) \\
36 & (9)\end{array}$ & $\begin{array}{r}362 \\
0\end{array}$ \\
\hline $\begin{array}{ll}\text { Diatoms } & \\
\quad \text { Centric } & (\bar{x}=47 \mu \mathrm{m}) \\
\text { Pinnate I } & (\bar{x}=86 \mu \mathrm{m}) \\
\text { Pinnate II } & (\bar{x}=154 \mu \mathrm{m})\end{array}$ & $\begin{array}{r}216 \\
126 \\
63\end{array}$ & $\begin{aligned} 835 & (18) \\
171 & (18) \\
86 & (18)\end{aligned}$ & $\begin{array}{r}203 \\
131 \\
60\end{array}$ & $\begin{array}{l}244 \\
106 \\
167\end{array}$ & $\begin{array}{ll}283 & (10) \\
181 & (10) \\
1.07 & (10)\end{array}$ & $\begin{array}{r}244 \\
169 \\
77\end{array}$ \\
\hline Tintinnids & 37 & $273(18)$ & 0 & 33 & $239(10)$ & 0 \\
\hline Limacina spp. $(<300 \mu \mathrm{m})$ & 3 & $53(12)$ & 0 & 2 & $33(10)$ & 0 \\
\hline Copepods (thorax $<500 \mu \mathrm{m}$ ) & 8 & $29(14)$ & 0 & 5 & $24 \quad(8)$ & 0 \\
\hline Ratios between taxa: & & & & & & \\
\hline Small cells/Dinoflagellates & 11.7 & 1.6 & 29.8 & 14.5 & 1.8 & 23.0 \\
\hline Small cells/Diatoms & 17.0 & 4.2 & 24.7 & 14.6 & 5.1 & 17.0 \\
\hline Dinoflagellates/Diatoms & 1.4 & 2.6 & 0.8 & 1.0 & 3.2 & 0.7 \\
\hline Dinoflagellates/Tintinnids & 15.8 & 10.8 & - & 15.4 & 6.7 & - \\
\hline Tintinnids/Limacina spp. & 12.3 & 5.2 & - & 16.5 & 7.2 & - \\
\hline Tintinnids/Copepods & 4.6 & 9.4 & - & 6.6 & 10.0 & - \\
\hline Limacina spp./Copepods & 0.4 & 1.8 & - & 0.4 & 1.4 & - \\
\hline Diatoms/Copepods & 50.6 & 31.7 & - & 101 & 20.9 & - \\
\hline Diatoms/Tintinnids & 10.9 & 4.1 & - & 15.4 & 2.1 & - \\
\hline Dinoflagellates/Copepods & 73.4 & 102 & - & 102 & 67.1 & - \\
\hline
\end{tabular}

Ingested diatoms were scored into 4 size categories: 1 large centric type (Table 1; Fig. 5d); 2 large pinnate forms (Pinnate Groups I and II in Table 1 ; Fig. $5 \mathrm{~d}$ ); and numerous small centric forms (ca $15 \mu \mathrm{m}$ average dimensions). Collectively the first 3 groups of diatoms contributed about $16 \%$ to total volume and $17 \%$ to estimated carbon in the gut contents.

The smallest cells categorized were small thecate dinoflagellates (Group I in Table 1; Fig. 5a). They contributed 11 to $12 \%$ of the total volume and 15 to $18 \%$ to the estimated carbon. Numerically they were the most abundant items identified (Tabie 2).

Five Limacina helicina had ingested fecal pellets produced by other zooplankton. These partially disrupted pellets measured $100 \times 400 \mu \mathrm{m}$ and contained many intact dinoflagellates and smaller cells (Fig. 5c). The identifiable intact material contained in these pellets was included in our cell counts.

Both water and net samples contained several taxa that were absent from the gut contents of Limacina helicina. These included small larvaceans (ca 300 to $400 \mu \mathrm{m}$ ), larval ctenophores, several different kinds of coelenterate larvae and small medusae. We did not find sarcodines in the gut contents either, but they were sparse in both the net tows and water samples. All of these organisms are soft-bodied, so they may have been rendered unrecognizable in the gut contents. Nevertheless, the comb plates of ctenophores are very resistant to degradation, and should have been observed in the gut contents had they been present.

\section{Fecal pellets}

Pellets from pteropods collected on the same dives as those used for gut content studies contained no whole items larger than $50 \mu \mathrm{m}$ (Fig. 4a). Diatoms appeared least affected by passage through the gut. Many appeared to be intact or had small irregular holes in the cell walls. About two-thirds of all the diatoms in the fecal pellets displayed bright red fluorescence, in all probability due to chlorophyll or its degradation products. Diatoms contributed twice as much to the volume of fecal material as they did to the volume of gut contents (Fig. 4a)

Less than half of the intact dinoflagellates in the pellets fluoresced. Many were broken into smaller fragments, but intact thecae were split about evenly 
between red-fluorescing and non-fluorescing cells. While cells between 10 and $20 \mu \mathrm{m}$ in diameter contributed as much as $91 \%$ of the total number of particles counted in fecal pellets, they constituted only about a third of the volume (Fig. 4a).

Small cells (10 to $20 \mu \mathrm{m}$ ) were much more abundant in the water samples and fecal material than in the gut contents. The small 'cells' in the fecal material consisted mainly of partially digested or degraded material, similar in appearance to that reported by Silver \& Bruland (1981)

Recognizable debris was present and consisted of distal points from tintinnid loricae and large fragments of crustacean exoskeleton segments (Fig. 5d, e). These

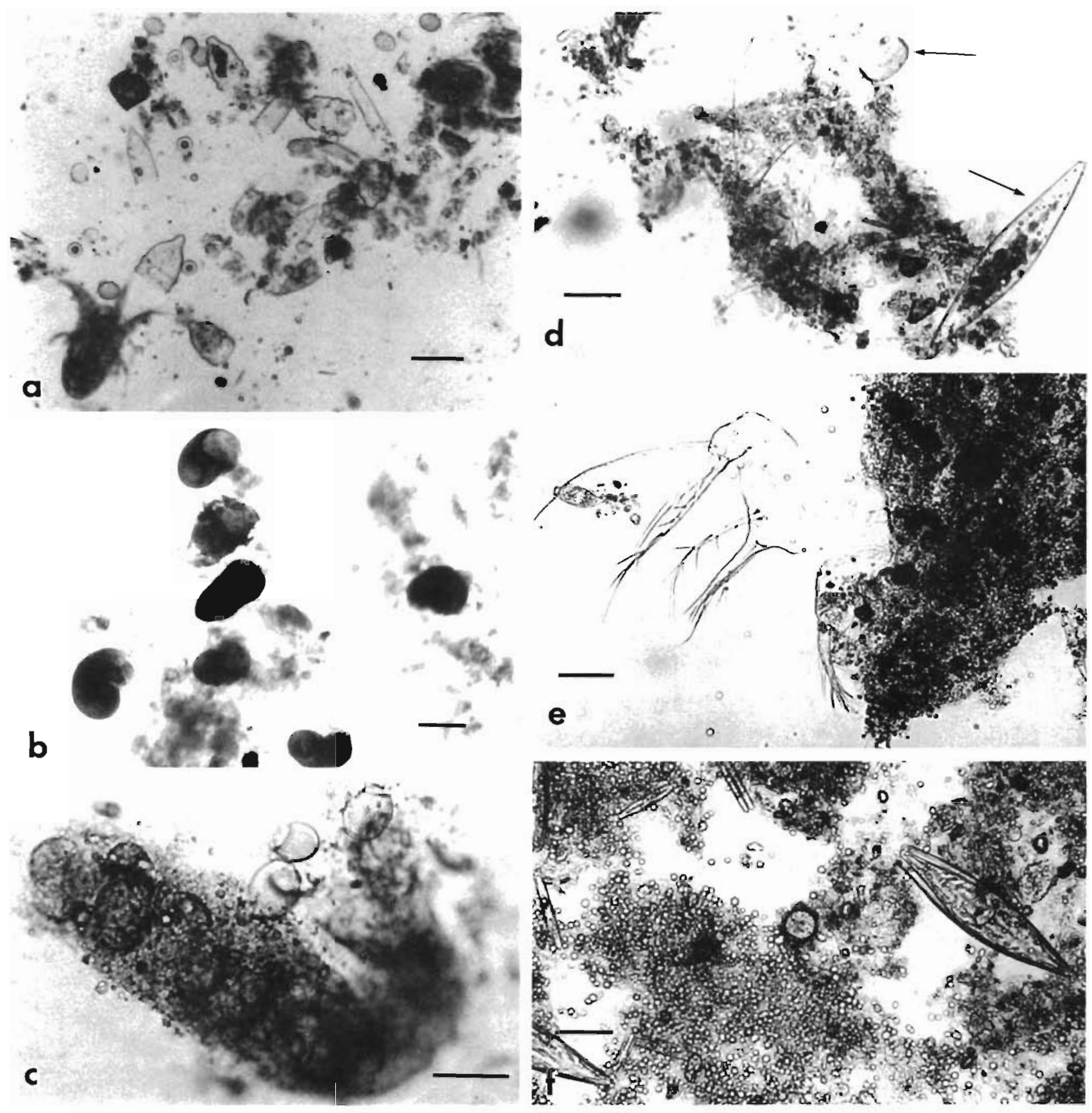

Fig. 5. Limacina helicina. Representative photographs of the contents of guts and fecal pellets. (a) Gut contents showing relative sizes of common prey items: copepod nauplii, tintinnids, and dinoflagellates. (b) Seven juvenile $L$. helicina in gut of an adult specimen. (c) Ingested fecal pellet with dinoflagellates, from gut contents of $L$. helicina. (d) Two kinds of diatoms commonly found in gut contents. (e) Fecal pellet containing large fragment of a copepod thorax. (f) Fecal pellet with diatoms containing chloroplasts. Scale bars: (a) $120 \mu \mathrm{m}$, (b) $100 \mu \mathrm{m}$, (c) $325 \mu \mathrm{m}$, (d) $230 \mu \mathrm{m}$, (e) $120 \mu \mathrm{m}$, (f) $200 \mu \mathrm{m}$ 
fragments were tallied and measured, and we estimated them to occupy between 21 and $27 \%$ of the total pellet volumes. They were not included in the volume summations in Fig. 4 or Table 2, however. No intact tintinnid loricae were found in any of the fecal material. Intact shells or large shell fragments of Limacina helicina juveniles and intact crustaceans were absent in the fecal matter, although both were present in the gut contents.

\section{Effect of residence time on gut contents}

No intact crustaceans were found in the digestive tracts of specimens held for $4 \mathrm{~h}$ before preservation ( $\mathrm{n}$ $=11$ ), although fragmentary material was present. In contrast, intact Limacina helicina juveniles were found in the guts of these pteropods and in the guts of those held for $10 \mathrm{~h}$ (Fig. 6). The contribution of $L$. helicina juveniles to the total volume of gut contents was approximately the same (ca $25 \%$ ) for specimens held for 4 and $10 \mathrm{~h}$. In the latter, however, the soft parts appeared to be more degraded. The overall volume of food in the guts of specimens was noticeably reduced in pteropods held for $10 \mathrm{~h}$, and 2 specimens had totally empty guts. From Fig. 6, it appears that tintinnids and copepods are digested more rapidly than diatoms.

\section{Numerical considerations}

A comparison of ratios between taxa in the water samples with ratios between taxa in the gut contents (Table 2 ) revealed a significant difference $(p=0.01)$ at

Dive 1870

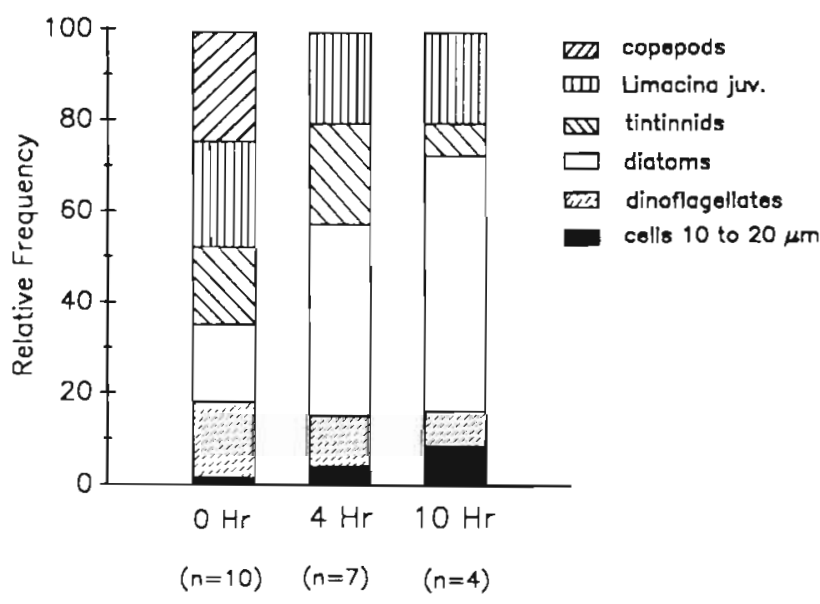

Fig. 6. Limacina helicina. Composition of gut contents as a function of residence time. Frequency (as \% total volume) shown for specimens preserved in situ $(0 \mathrm{~h})$, held for $4 \mathrm{~h}$ before preservation, or held for $10 \mathrm{~h}$ before preservation both sampling stations (Chi-square or KolmogorovSmirnov 2-group test). Fecal pellets contained much higher numbers of small cells relative to either dinoflagellates or diatoms when compared either to water samples or to gut contents. Dinoflagellates were 2 to 3 times more abundant than diatoms in the gut contents, yet were about equal in abundance in both water samples and fecal pellets (Table 2). This suggests either that dinoflagellates may be more easily digested than diatoms, or that diatoms are less susceptible to mechanical degradation by the gizzard. The frequency with which these cells occur relative to each other in water and gut samples also implies that dinoflagellates are collected at 3 times the rate of diatoms. The 8 -fold decrease in small cells compared with dinoflagellates in the gut contents (Table 2) may simply reflect the difficulty of identifying smaller cells.

The ratios also showed that juvenile Limacina spp were ingested at about 4 times the rate of crustaceans. Tintinnids were ingested at up to 7 times the rate of diatoms and up to 2.3 times the rate of dinoflagellates. Copepods were collected at 50 to $80 \%$ lower rates than Limacina spp. juveniles, and 50 to $66 \%$ lower rates than tintinnids.

\section{DISCUSSION}

The Limacina helicina in our study acquired almost half of their diet by cannibalism and ingestion of small crustaceans. This obviously important fraction was not evident in either fecal pellets or guts of pteropods kept alive for more than a few hours before preservation. $L$. helicina defecates or regurgitates food when rapidly preserved, or if left confined in a collection jar. Some specimens defecated within 1 min of capture. In addition, large females often spawn in the jar, releasing large amounts of eggs and mucus. This material becomes entangled with the fecal matter and regurgitated food, making it extremely difficult to collect all of the ingested food items as the time between capture and preservation increases. The contents of each jar must be carefully examined to be sure that no food items are overlooked.

Large fragments of tintinnid loricae and copepod exoskeletons often occurred in fecal pellets, whereas no Limacina spp. shell fragments were found. Copepod fragments measuring ca 800 um (Fig. 5e) were present in several fecal pellets, indicating that larger crustaceans than those we sampled can be eaten. It is also possible that these larger fragments were simply detrital material that had become stuck on the web. We have found 5 intact copepods ( $3.1 \mathrm{~mm}$ thorax length) in the gut of a single $L$. helicoides collected discretely at $800 \mathrm{~m}$ with the Johnson Sea-Link submersible, how- 
ever. This specimen had a shell diameter of ca $15 \mathrm{~mm}$ (only slightly larger than specimens of $L$. helicina examined in this study). Thus, L. helicina may ingest much larger copepods than we sampled, and large zooplankton probably constitute a sizeable fraction of the diet of other limacinids as well.

The apparently rapid disappearance of intact copepods in the residence-time experiments (Fig. 6) poses a problem in interpretation. It should be noted that pieces of copepod exoskeletons were present in the gut contents, which suggests that these crustaceans were rapidly digested. Alternatively, the copepods could have been regurgitated during the experiments, although there is no reason to expect that this group would be preferentially regurgitated. Since we used different specimens in this series of experiments, variability in the results could be due in large part to differences in previous feeding history. Further, since $L$. helicina does not feed in the laboratory, these experiments were done on starved specimens, which could have affected the results.

Although the percent contribution of intact Limacina spp. juveniles to total volume was essentially unchanged during the course of the residence-time experiments (Fig. 6), the absolute amount of material was greatly reduced, indicating that these animals were being digested as well. The absence of intact shells and large shell fragments from the fecal material of freshly collected specimens (Fig. 4, Table 2) suggests that the shells are ultimately broken apart after a period of dissolution in the gut. This, together with the rapid disappearance of intact copepods, suggests that the gizzard may be able to triturate material that has already passed through it into the stomach. However, since the residence-time experiments could have been biased by previous feeding history and the unnatural conditions under which the pteropods were held in the laboratory, this suggestion should be regarded as speculative.

There are considerable difficulties with our identification and measurements of the smallest size fraction. The walls of the gizzard sac and esophagus of Limacina helicina often broke apart during dissection and became mixed with the gut contents, undoubtedly accounting for many of the unidentified cells in the 10 to $20 \mu \mathrm{m}$ range. Also, many of the tintinnids were separated from their loricae (Fig. 5a, d) so we only counted intact loricae in the water and gut content samples (Fig. 4). The soft parts could sometimes be identified in the guts, but were never identifiable in the fecal matter. Aloricate ciliates, including a plastidic oligotrich Strombidium sp. $(70 \times 40 \mu \mathrm{m})$, were numerous in the upper water column at most stations, including our study sites (Putt 1990), but were never found in the gut contents or fecal pellets.

We have probably overestimated the contribution of small particles to the diet of Limacina helicina. We assigned greater-than-average volumes to the small size classes (Table 1), and did not subtract those cells that appeared to pass through the gut intact. Determining the importance of the smaller cells as food was made more difficult since it was not possible to assess their condition with light microscopy, as we could do with the larger food items. Further, the contribution of the larger size fraction was probably underestimated, since we used mean values for volume calculations, which do not reflect the great size variation within the metazoan fraction. Taking all these factors into account, we regard our results as conservative estimates.

The taxonomic ratios (Table 2 ) indicate that Limacina helicina traps motile unicellular and metazoan organisms at levels above their concentrations in the water. Since limacinids have no mechanism for moving water through the web (Gilmer \& Harbison 1986), all evidence suggests that they are trappers, rather than true filter feeders. One method of trapping motile prey might be the attraction of these organisms into the feeding web, a hypothesis we have suggested previously (Gilmer \& Harbison 1986). Such an attraction must be chemical in this case, since limacinids lack the brightly colored mantle appendages of other pteropods, and it must at this juncture be considered as speculative. Another more likely possibility is that limacinids are employing a strategy similar to that of spiders, and deploy mucous webs to capture the more motile organisms that blunder into them. An indirect piece of evidence for this is the reaction of limacinids and other euthecosomes to slight turbulence (Gilmer \& Harbison 1986). Slight turbulence, such as might be caused by a struggling organism, will cause rapid ingestion of the web. In fact, at least one gymnosome pteropod, Pneumodermopsis canephora, captures its thecosome prey by attaching to the mucous web and allowing itself to be drawn onto its prey as the web is rapidly ingested (Lalli \& Gilmer 1989). In addition, $L$. helicina may be able to sense the presence of elevated prey abundance, since the vertical distributions of this species and of prey-sized copepods within the upper $30 \mathrm{~m}$ are similar (Fig. 2).

Limacina helicina often occurs in shallow zones of high abundance throughout much of the Arctic and subarctic regions (Hansen \& Dunbar 1970, Kobayashi 1974). Hansen \& Dunbar (1970) found Limacina spp. present at densities of up to 24 ind $\mathrm{m}^{-3}$, resulting in pronounced acoustic scattering layers between 35 and $55 \mathrm{~m}$. Their specimens were much smaller (maximum shell diameter ca $1 \mathrm{~mm}$ ) than the ones we studied, and it is doubtful that larger zooplankton could play much of a role in their diet. Nevertheless, motile phytoplankton and protozoans could be captured preferentially even by these smaller specimens. Hopkins (1987) found that 
the Antarctic variety of $L$. helicina accounted for $23 \%$ of the total biomass in the upper $800 \mathrm{~m}$ of the Ross Sea. He concluded from examination of the gut contents of 30 specimens that they fed only on phytoplankton. His specimens were also small, averaging $2.6 \mathrm{~mm}$ in shell diameter. Thus, it is possible that smaller specimens are herbivores, and switch to omnivory only at larger sizes.

Nevertheless, our study shows that Limacina helicina is an opportunistic feeder at larger sizes. Its ability to switch from herbivory to omnivory would be of obvious advantage in protecting it from the precipitous declines in phytoplanktonic food levels that occur after blooms in the subarctic and temperate regions. We have recently made Antarctic collections of $L$. helicina in McMurdo Sound. Our collections included many specimens up to $7 \mathrm{~mm}$ in shell diameter. Ultimately it may be possible to determine at what size L. helicina can effectively feed as a carnivore and what other factors, such as time of year and prey abundance, can influence its dietary switch.

Acknowledgements. We thank the captain and crew of the RV 'Endeavor' for their help; G. R. Dietzmann, J. Lindsey, G. Matsumoto, C. Mann, D. Backus, T Falkenhaug, R. Larson and N. Wu for diving assistance; P. Hernandez for laboratory help at sea; and M. Putt for providing station data on ciliates and chlorophyll. Research supported by N.S.F. Grants OCE 8516083, OCE 87-46136 and DPP 86-13388 to G. R. H. Harbor Branch Oceanographic Institution Contribution No. 792.

\section{LITERATURE CITED}

Bé, A. W H., Gilmer, R. W (1977). A zoogeographic and taxonomic review of euthecosomatous pteropoda. In: Ramsey, A. T S. (ed.) Oceanic micropaleontology, Vol. 1. Academic Press, London, p. 733-808

Boas, J. E. V. (1886) Zur Systematik und Biologie der Pteropoden. Zool. Jb. 1: 311-340

Conover, R. J., Lalli, C. M. (1974). Feeding and growth in Clione limacina (Phipps), a pteropod mollusc. II. Assimilation, metabolism, and growth efficiency. J. exp. mar. Biol. Ecol. 16: 131-154

Gilmer, R. W (1974). Some aspects of feeding in thecosomatous pteropod molluscs. J. exp. mar. Biol. Ecol. 15: 127-144

Gilmer, R. W. (1990). In situ observations of feeding behavior of thecosome pteropod molluscs. Am. malac. Bull. 8(1): 53-59

Gilmer, R. W., Harbison, G. R. (1986). Morphology and field behavior of pteropod molluscs: feeding methods in the families Cavoliniddae, Limacinidae and Peraclididae (Gastropoda: Thecosomata). Mar Biol. 91 47-57

Hamner, W. M. (1975). Underwater observations of blue water plankton: logistics techniques, and safety procedures for divers at sea. Limnol. Oceanogr 20: 1045-1051

Thus article was presented by R. S. Scheltema, Woods Hole, Massachusetts, USA
Hamner, W M., Carlton, J. (1979). Copepod swarms attributes and role in coral reef ecosystems. Limnol Oceanogr 24:1-14

Hansen, W. J., Dunbar, M. J. (1970). Biological causes of scattering layers in the Arctic Ocean. In: Farquhar, G. B. (ed.) Proceedings of an international symposium on biolog1cal sound scattering in the ocean. U.S. Navy, Washington, D.C., p. 508-526

Hopkins, T. (1987). Midwater food web in McMurdo Sound, Ross Sea, Antarctica. Mar. Biol. 96: 93-106

Ishimaru, T., Nishida, S., Marumo, R. (1988). Food size selectivity of zooplankton evaluated from the occurrence of coccolithophorids in the guts. Bull. Plankton Soc. Japan 35: 101-114

Kobayashi, H. A. (1974). Growth cycle and related vertical distribution of the thecosomatous pteropod Spiratella (Limacina) helicina in the central Arctic Ocean. Mar. Biol. 26: 295-301

Lalli, C. M., Gilmer, R. W. (1989). Pelagic snails: the biology of holoplanktonic gastropod mollusks. Stanford University Press, Palo Alto

Martens, F. (1675). Spitzbergische oder grönlandische Reise Beschreibung gethan im Jahr 1671. Schultzen, Hamburg

McGowan, J. A. (1963). Geographical variation in Limacina helicina in the North Pacific. In: Speciation in the sea. Syst Ass. Publ. 5: 109-128

Meisenheimer, J. (1905). Pteropoda. Wiss. Ergebn. dt. Tiefseeexped 'Valdivia' 9: 1-314

Mironov, G. N. (1977). On the composition of the stomach contents in the young stages of Thecosomata (Mollusca, Pteropoda) from the tropical ocean areas. Biol. Morya, Kiev 42: 33-39 (in Russian)

Morton, J. E. (1954). The biology of Limacina retroversa. J. mar. biol. Ass. U.K. 33: 297-312

Mullin, M. M., Brooks, E. R. (1970). Laboratory culture, growth rate, and feeding behavior of a planktonic marine copepod. Limnol. Oceanogr. 12: 657-665

Mullin, M. M., Sloan, P. R., Eppley, R. W. (1966). Relationship between carbon content, cell volume, and area in phytoplankton. Limnol Oceanogr. 11: 307-311

Putt, M. (1990). Abundance, chlorophyll content and photosynthetic rates of ciliates in the Nordic Seas during summer. Deep Sea Res. 37(11A): 1713-1731

Richter, G. (1977). Jäger, Fallensteller und Sammler (zur Ernährung planktischer Schnecken). Natur Mus., Frankf. 107: $221-234$

Silver, M. W., Bruland, K. W (1981). Differential feeding and fecal pellet composition of salps and pteropods, and the possible origin of the deep-water flora and olive-green 'cells' Mar. Biol. 62: 263-273

Tesch, J. J. (1913). Pteropoda. In: Schulze, F. E. (ed.) Das Tierreich, Vol. 36. Friedländer \& Sohn, Berlin, p. 1-154

van der Spoel, S. (1967). Euthecosomata: a group with remarkable developmental stages (Gastropoda, Pteropoda). J. Noorduijn, Gorinchem

Verity, P. G., Langdon, C. (1984). Relationships between lorica volume, carbon, nitrogen, and ATP content of tintinnids in Narragansett Bay. J. Plankton Res. 6: 859-868

Yonge, C. M. (1926). Ciliary feeding mechanisms in the thecosomatous pteropods. J. Lirn. Soc. (Zool.) 36: 417-429

Manuscript first received: May 15, 1990

Revised version accepted. September 18, 1991 